\title{
KRONIKA BIBLIJNA
}

W dniu 13 lipca 1998 r. w Ambasadzie Rzeczypospolitej Polskiej w Paryżu miała miejsce podniosła uroczystość odznaczenia wybitnego polskiego uczonego, Józefa Tadeusza Milika, światowej sławy badacza tekstów z Qumran. Okazją do uhonorowania uczonego stał się potrójny jubileusz obchodzony w 1997 roku: 50-lecie odkryć w Qumran, tyleż samo pracy naukowej Milika oraz jego 75. urodziny. Laudację wygłosił ambasador RP we Francji, prof. S. Meller, który stwierdził na zakończenie, że J.T. Milik ,jest uczonym, którego polskie nazwisko jest chwałą polskiej humanistyki”. Aktu dekoracji Krzyżem Oficerskim Orderu Zasługi Rzeczypospolitej dokonał minister spraw zagranicznych RP, prof. B. Geremek, który powiedział: „Prof. Milik jest żywą legendą odkryć biblijnych w Qumran”. W uroczystości wzięli udział wybitni francuscy badacze archeologii i biblistyki, wśród których ks. prof. J. Briend $\mathrm{z}$ Institut Catholique w Paryżu, prof. E.M. Laperrousaz z Sorbony czy prof. A. Lemaire z Ecole Pratique des Hautes Etudes przy paryskiej Sorbonie. Z Polski był obecny dr Z. Kapera, znany polski kumranista i organizator zjazdów kumrańskich w Polsce, edytor „The Qumran Chronicle" i wieloletni przyjaciel J.T. Milika. Uroczystość doszła do skutku dzięki inicjatywie i wysiłkom dyrektora Biblioteki Polskiej w Paryżu p. Leszka Talko i p. Dariusza Długosza z Muzeum w Luwrze.

Zmarł na atak serca, krótko przed swoimi 70. urodzinami, ks. prof. Raymond E. Brown, sulpicjanin, wykładowca Nowego Testamentu przez dwadzieścia lat w Studium Biblijnym Union Theological Seminary w Nowym Jorku. Światowej sławy biblista był dwukrotnie członkiem Papieskiej Komisji Biblijnej, a przez 27 lat członkiem Faith and Order Comission przy Światowej Radzie Kościołów. Pełnil funkcje przewodniczącego organizacji biblijnych, takich jak: Catholic Biblical Association, Society of Biblical Literature, Studiorum Novi Testamenti Societas. Autor 25 książek, otrzymał 24 różne odznaczenia i honorowe doktoraty. 